\title{
Landslide Susceptibility Zonation Mapping in Post- Earthquake Scenario in Gorkha District
}

\author{
Him Lal Shrestha ${ }^{1}$ and Mahesh Poudel ${ }^{2}$
}

\begin{abstract}
Landslide hazard zonation map is prepared to assist planners to implement mitigation measures so that further damage and loss can be minimized. In this study, post 25 April 2015 earthquake remote sensing data were used to prepare landslide inventory. Landsat images after the earthquake were downloaded from the National Aeronautics and Space Administration (NASA) website and processed using ArcGIS, ERDAS imagine and Analytical Hierarchy Process (AHP) as an extension in ArcGIS. The study was carried out in Gorkha district as this was the epicenter of the main earthquake of 25 April 2015 and consequently was highly affected by earthquake triggered landslide. The digital imagery was processed to analyze land use/land cover type. Geological features were analyzed using the criteria like color, tone, topography, stream drainage, etc. Primary topographic features like slope, aspect, elevation, etc. were generated from Digital Elevation Model (DEM). Seismological data (magnitude and epicenter) were obtained from Department of Seismology. For Landslide Susceptibility Zonation (LSZ) different thematic maps like Land Use and Land Cover (LULC) map, slope map, aspect map, lithological map, buffer map (distance from road and river/water source), soil map, and seismological map were assigned relative weights on the ordinal scale to obtain Landslide Susceptibility Index (LSI). Threshold values were selected according to breaks in LSI frequency and a LSZ map was prepared which shows very low, low, moderate, high, very high hazard zones in Gorkha district.
\end{abstract}

Keywords: landslide hazard zonation map, landslide susceptibility index, digital elevation model, land use land cover

Shrestha H. L., Poudel M. (2018): Landslide susceptibility zonation mapping in Post-Earthquake scenario in Gorkha District. Forestry: Journal of Institute of Forestry, Nepal. No. 15: page 45 to 56.

${ }^{1}$ eG-Tech Pvt. Ltd., Lalitpur, Nepal, Author corresponding email address: hlshrestha@gmail.com ${ }^{2} e G$-tech Pvt. Ltd., Lalitpur, Nepal 


\section{Introduction}

Landslide is a result of a wide variety of geoenvironmental processes, which include geological, meteorological and human factors. The main factors which influence landslides were discussed by Varnes (1984) and Hutchinson (1995). Most important inherent factors are bedrock geology (slope gradient, aspect, and relative relief), soil (depth, structure, permeability, and porosity), land use- land cover and hydrologic conditions. Local influence such as relative relief, proximity to drainage and proximity to lineament are very important for landslide trigger (Anbalagan et al. 2014). Landslides are triggered by many extrinsic causative factors such as earthquake, blasting and drilling, cloudburst, flash-foods (Anbalagan 1992). Application of GIS and remote sensing is inevitable in large scale landslide inventory, landslide investigation and susceptibility zonation for landslide occurrence. Remote sensing, especially from the high-resolution satellite imagery is gaining the high importance due to its wide coverage (Delacourt et al. 2007). Landslide hazard zonation mapping is the mapping of the probable landslide occurrence within the specific area considering specific contributing factor. Multispectral satellite imagery was used to delineate the landslides and to determine drainage and geology whereas, Digital Elevation Model (DEM) of the study area was used for the extraction of terrain parameters like slope, aspect, elevation etc. Earthquake induced landslides are very prone in a mountainous country like Nepal. 7.6 Richter scale magnitude earthquake stroked in Nepal with an epicenter near to Barpak of Gorkha district. Numerous landslides occurred aftermath the earthquake of 25 April 2015 and its aftershocks.

\section{Materials and Methods}

Site description

The study was conducted in the Barpak VDC of Gorkha district. The area was the epicenter of Gorkha earthquake on 25 April 2015 of 7.9 Magnitude Richter scale. The area is very prone to landslide and is located between Budigandaki and Daraundi rivers. The study was carried out within the area of 33596 ha. It has a central longitude/latitude of $84^{\circ} 46^{\prime} \mathrm{E}$ and $28^{\circ} 07^{\prime} \mathrm{N}$. The location of the study area is shown in Fig. 1. 


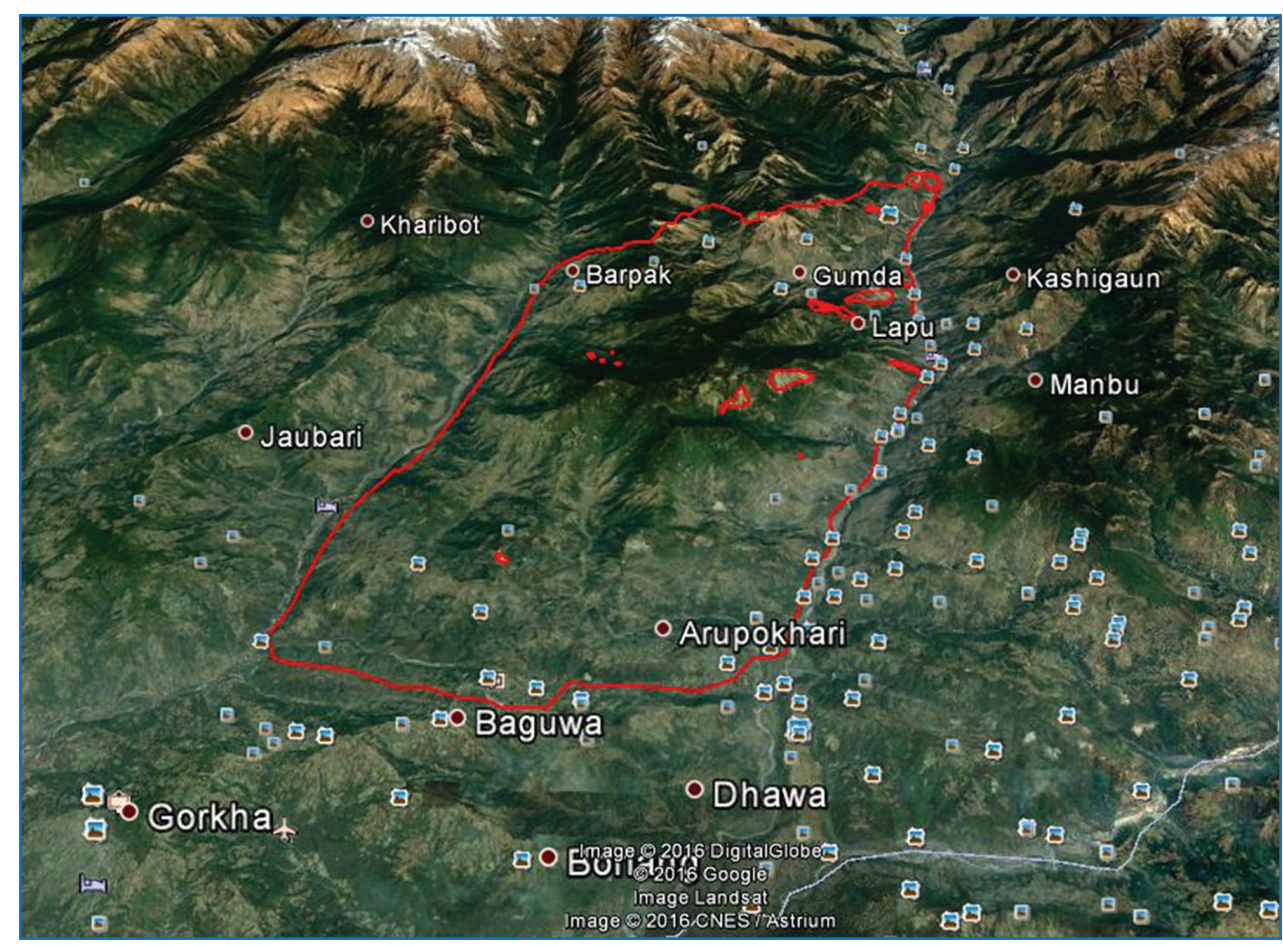

Fig. 1: Study area around the epicenter of Earthquake of Nepal in 25 April 2015

\section{Data, tools, and software}

Landslide hazard zonation demands different data from different sources i.e. Digital Elevation Model (DEM) and their derivatives, satellite images, geological layers, land use land cover layers, seismic information and landslide occurrence data. The data, tools and software used for landslide hazard zonation are presented in Table 1. 
Table 1: Data, Tools and Software used for the analysis and their source

\begin{tabular}{|c|c|c|}
\hline Name & Resolution/Details & Source \\
\hline \multicolumn{3}{|l|}{ Data } \\
\hline DEM & Raster, 30m & www.nasa.gov.np \\
\hline Landsat images & Raster, 30m & www.nasa.gov.np \\
\hline $\begin{array}{l}\text { Geological layer } \\
\text { River and road } \\
\text { network layer }\end{array}$ & $\begin{array}{l}\text { Shape file/Attributes } \\
\text { Shape file } \backslash \text { Attributes }\end{array}$ & $\begin{array}{l}\text { Department of Mines and Geology } \\
\text { Department of Survey }\end{array}$ \\
\hline $\begin{array}{l}\text { Land use Land cover } \\
-2010\end{array}$ & Raster, $30 \mathrm{~m}$ & ICIMOD Mountaingeoportal \\
\hline Seismic Information & $\begin{array}{l}\text { Geographic } \quad \text { Lat } / \\
\text { Long }\end{array}$ & Department of Seismology \\
\hline Landslide & Polygon & Google Earth \\
\hline \multicolumn{3}{|l|}{\begin{tabular}{|l} 
Software and Tools \\
\end{tabular}} \\
\hline ArcGIS 10.x & $\begin{array}{|lcc|}\text { Allows to } & \text { process } \\
\text { Raster } & \text { and } & \text { Vector } \\
\text { layers } & & \\
\end{array}$ & https://www.esri.com/en-us/home \\
\hline ERDAS Imagine 2013 & \begin{tabular}{|l|} 
Allows to process \\
Raster data
\end{tabular} & $\begin{array}{l}\text { http://www.hexagongeospatial.com/ } \\
\text { products/power-portfolio/erdas- } \\
\text { imagine }\end{array}$ \\
\hline AHP Tool & $\begin{array}{l}\text { Allows to process the } \\
\text { tabular analysis }\end{array}$ & $\begin{array}{l}\text { http://www.arcgis.com/home/item. } \\
\text { html?id=bb3521d775c94b28b69a } \\
\text { 10cd184b7c1f }\end{array}$ \\
\hline Google Earth Pro & $\begin{array}{l}\text { Allows to process } \\
\text { and visualize the } \\
\text { Geospatial layers } \\
\text { more user-friendly }\end{array}$ & $\begin{array}{l}\text { https://www.google.com/earth/ } \\
\text { download/gep/agree.html }\end{array}$ \\
\hline
\end{tabular}

\section{Methodology}

The set of data were acquired from different sources as required for the analysis of LSI as a function of topographic factors i.e. slope, relief and aspects, geological condition, distance to the roads and river networks, land use land cover pattern, seismic information and existing landslide areas (Fig. 2).

Data preparation was done in the first hand. ASTER DEM was downloaded from NASA website. Some DEM enhancement techniques like DEM fill, sink removal, etc., were applied for the higher accuracy. From the DEM, slope, relative relief, drainage pattern were derived. Aspect was not used as the area of study had a homogeneous aspect. River and road layers were collected from the Department of Survey (DoS) and validated. Land use and land cover data were downloaded 
from geoportal of International Centre for Integrated Mountain Development (ICIMOD). Geological and soil data were collected from Department of Mines and Geology (DMG). Seismic information like epicenter, magnitude of main earthquake and aftershocks along with the place of occurrence were obtained from DMG. All ancillary data were validated and made homogenous with regard to the spatial extent and coordinate system in GIS environment. Landslide inventory map was prepared based on field data and satellite images. Each thematic layers were assigned a particular weight on the ordinal scale to obtain landslide susceptibility index. Thus obtained landslide susceptibility index was then used to generate landslide susceptibility zonation map.

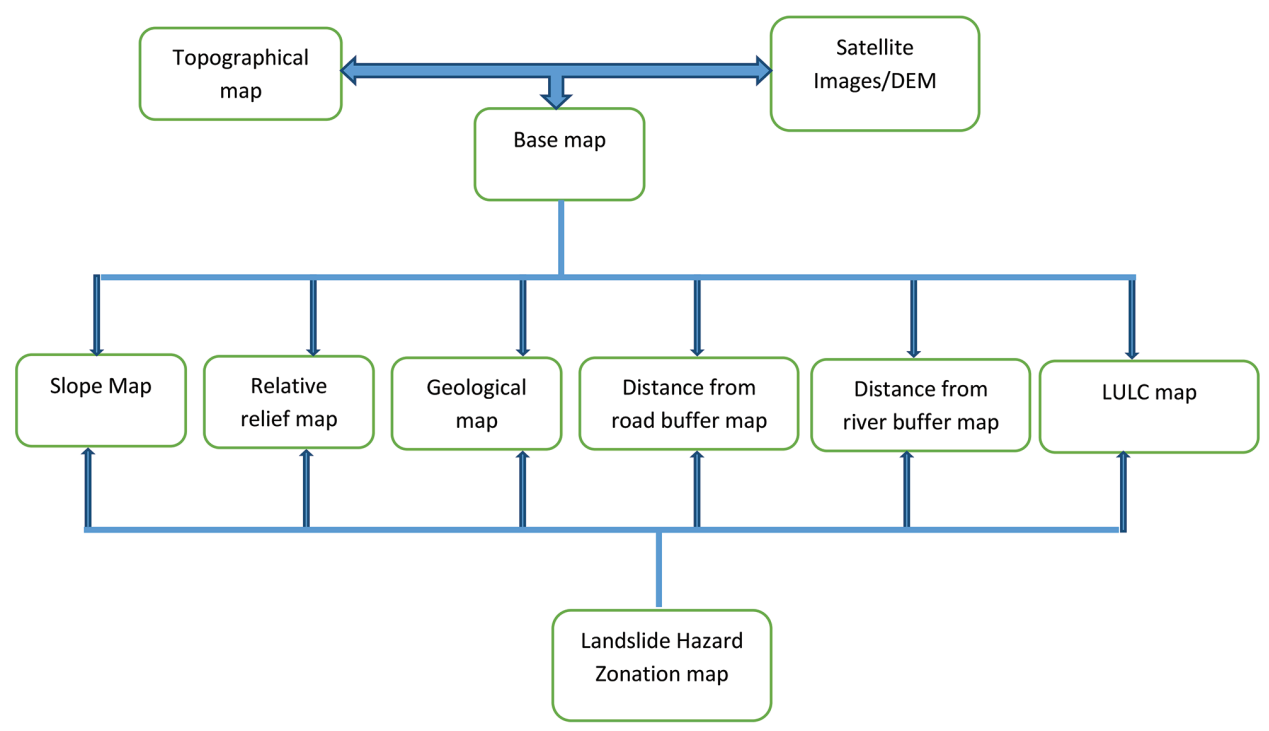

Fig. 2: Methodological framework adopted during research

\section{Earthquake data and layer preparation}

Seismic data of the main earthquake and aftershocks were gathered DMG. Latitude and longitudes were plotted in GIS environment and raster layer was prepared using 'Empirical Bayesian Kriging' tool.

\section{Landslide inventory}

Google Earth platform was used to know about the condition of the landslide. Landsat imagery before and after the date of the earthquake was analyzed to know whether the landslide were old or new due to the earthquake. Imageries were 
zoomed to significant level of resolution and delineated by drawing the polygon in the same platform. These polygons were then exported to GIS environment for further analysis.

\section{Derivative products}

Different derivatives were made to make a landslide susceptibility zonation map like; distance from river and road buffer map, relative relief map, slope map, LULC map, seismic map and geological map. These are prepared in ArcGIS environment. Buffering tool was used to make buffer maps.

\section{Analytical hierarchy process (AHP)}

Analytical Hierarchy Process (Saaty 1980) was used to compute landslide susceptibility index (LSI). For this, firstly, the factors that were identified responsible for triggering/causing landslide based on the field knowledge were assigned different weightage based on their importance using weighted rating system (Gupta et al. 1999). Different factors such as geology, slope, relief, distance from road, distance from river, distance from epicenter and land use were assigned different weights ranging from 0 to 1 where 0 stands for the class which has minimum impact and 1 stands for the class which has a maximum impact (Table 2).

Table 2: Weightage to various parameters

\begin{tabular}{|l|l|}
\hline Layer Name & Weight given \\
\hline Distance from river & 0.38 \\
\hline Relief & 0.24 \\
\hline Geology & 0.15 \\
\hline Seismic & 0.10 \\
\hline Land use & 0.07 \\
\hline Distance from road & 0.04 \\
\hline Slope & 0.03 \\
\hline
\end{tabular}

Secondly, the factors were categorized into different factor classes and were then ranked using the categories of the values of every factors (Table 3 ). 
Table 3: Factor classes and their ranks in Landslide Susceptibility Index (LSI)

\begin{tabular}{|c|c|c|c|}
\hline Parameters & Categorization & Value & Ranking \\
\hline \multirow[t]{6}{*}{ Slope } & Very low & $<20$ & 3 \\
\hline & Low & $20-30$ & 5 \\
\hline & Moderate & $30-40$ & 6 \\
\hline & Moderately high & $40-50$ & 7 \\
\hline & High & $50-60$ & 9 \\
\hline & Very high & $>60$ & \\
\hline \multirow[t]{6}{*}{ LULC } & Close Forest & & 2 \\
\hline & Open Forest & & 5 \\
\hline & Shrub land/grassland & & 2 \\
\hline & Agriculture & & 6 \\
\hline & Bare land & & 8 \\
\hline & River & & restricted \\
\hline \multirow[t]{5}{*}{ Relative relief } & Very low & $<500 \mathrm{~m}$ & 2 \\
\hline & Low & $500-1000 \mathrm{~m}$ & 3 \\
\hline & Moderate & $1000-2000 \mathrm{~m}$ & 5 \\
\hline & High & $2000-3000 \mathrm{~m}$ & 7 \\
\hline & Very high & $>3000 \mathrm{~m}$ & 9 \\
\hline \multirow[t]{5}{*}{ Dist. From River } & Very near & $0-1 \mathrm{~km}$ & 2 \\
\hline & Near & $1 \mathrm{~km}-2 \mathrm{~km}$ & 3 \\
\hline & Moderate & $2-3 \mathrm{~km}$ & 5 \\
\hline & Far & $3-4 \mathrm{~km}$ & 7 \\
\hline & Very far & $4-5 \mathrm{~km}$ & 9 \\
\hline \multirow[t]{5}{*}{ Distance from road } & Very near & Up to $1 \mathrm{~km}$ & 2 \\
\hline & Near & $1-2 \mathrm{~km}$ & 3 \\
\hline & Moderate & $2-3 \mathrm{~km}$ & 5 \\
\hline & Far & $3-4 \mathrm{~km}$ & 7 \\
\hline & Very far & $4-5 \mathrm{~km}$ & 9 \\
\hline \multirow[t]{5}{*}{ Dist. From Epicenter } & Very near & $4-4.2 \mathrm{~km}$ & 2 \\
\hline & Near & $4.2-4.4 \mathrm{~km}$ & 3 \\
\hline & Moderate & $4.4-4.6 \mathrm{~km}$ & 5 \\
\hline & Far & $4.6-4.8 \mathrm{~km}$ & 7 \\
\hline & Very far & & 9 \\
\hline \multirow[t]{6}{*}{ Geology } & Himal group & & 2 \\
\hline & Ghanapokhara formation & & 2 \\
\hline & Ranimatta formation & & 5 \\
\hline & $\mathrm{Cr}$ & & 5 \\
\hline & Basic rocks & & 6 \\
\hline & Ulleri formation & & 7 \\
\hline \multirow[t]{5}{*}{ Aspect } & Flat & & Restricted \\
\hline & North & & 5 \\
\hline & South & & 7 \\
\hline & East & & 3 \\
\hline & West & & 4 \\
\hline
\end{tabular}


Finally, Landslide Susceptibility Index (LSI) was calculated using following equation.

$L S I=($ Slope $* 0 / 03)+(L U L C * 0.07)+($ Relative relief $* 0.24)+($ Dist. from river $*$ $0.38)+($ Dist. from road $* 0.04)+($ Dist. from epicenter $* 0.10)+($ Geology $* 0.15)$

The equation is applied to calculate LSI value at pixel level of raster calculation using the values of the factors.

\section{Results and Discussion}

\section{Landslide inventory}

Landsat imageries from the Google Earth platform were used to make the landslide inventory map. The pre and post-earthquake imageries were analyzed to study the landslide, debris accumulation and depth of landslide. Numerous landslides were observed in the imageries, however, only the significant and larger ones greater than 1 ha were considered for this study (Fig. 3).

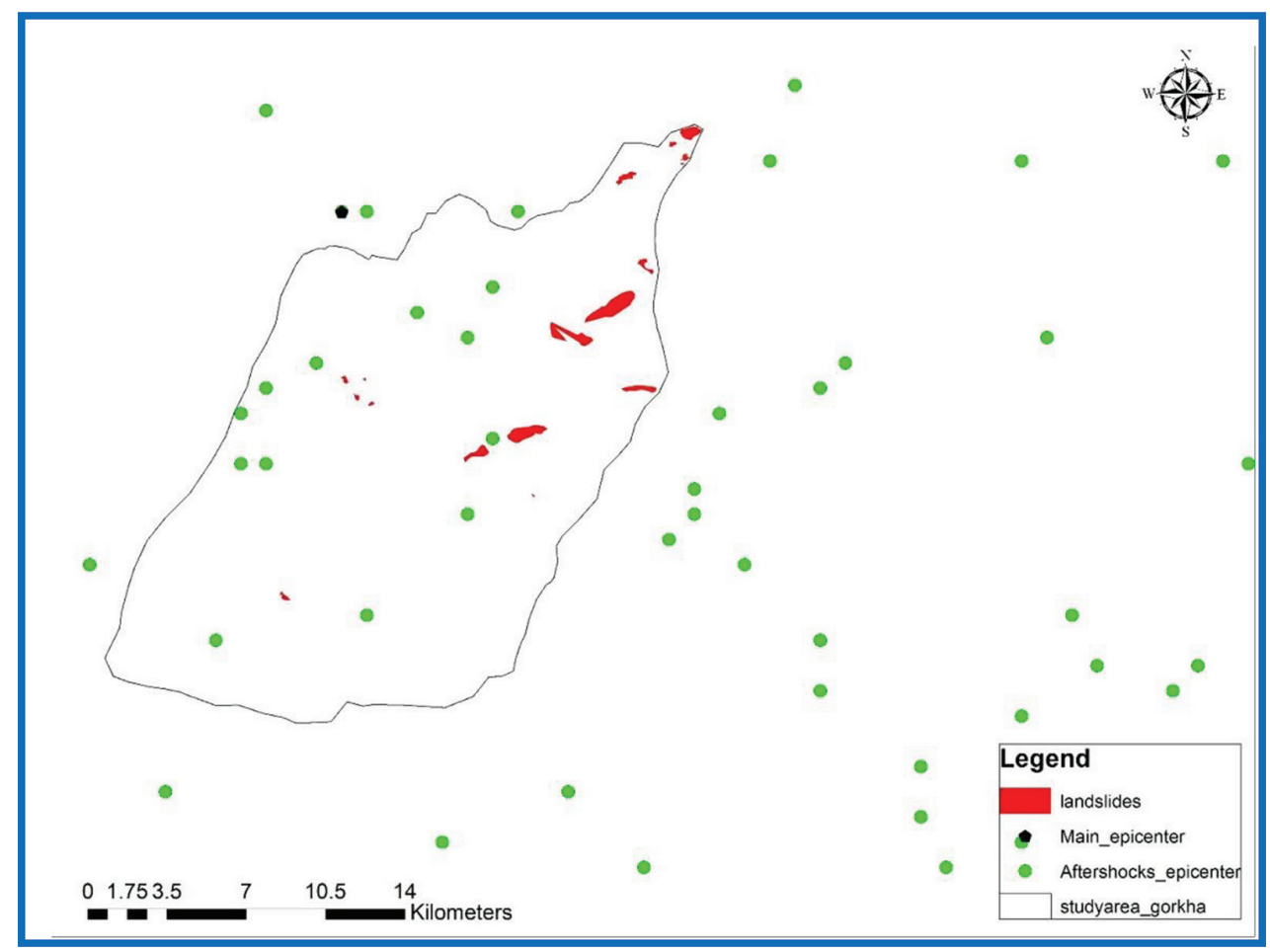

Fig. 3: Landslide Inventory map showing epicenters 


\section{Pair wise comparison}

A pair wise comparison of the landslide triggering factors was carried out and the output tables are presented below (Fig. 4 and Table 4);

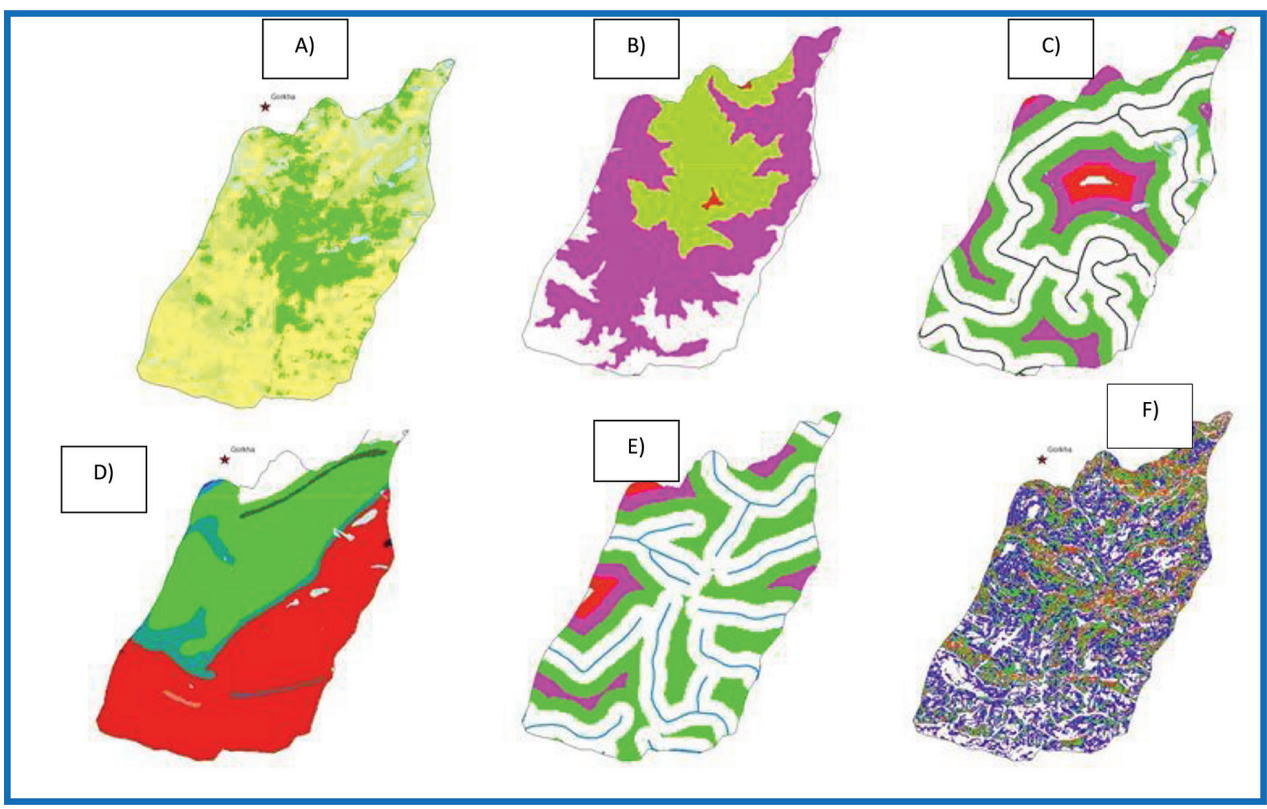

Fig. 4: Landslide triggering/causing factor layers used in this study: A) Land use Land cover map B)Relief map C) Road buffer map D) Geological map E) River buffer map F) slope map.

Table 4: LSI analyzed through Analytical Hierarchy Tool

\begin{tabular}{|l|c|c|c|c|c|c|c|}
\hline & $\begin{array}{c}\text { Distance } \\
\text { from river }\end{array}$ & Relief & Geology & Seismic & Land Use & $\begin{array}{c}\text { Distance } \\
\text { from road }\end{array}$ & Slope \\
\hline $\begin{array}{l}\text { Distance } \\
\text { from river }\end{array}$ & 1 & 3 & 4 & 5 & 6 & 5 & 7 \\
\hline Relief & .333 & 1 & 3 & 3 & 4 & 7 & 9 \\
\hline Geology & 0.25 & .333 & 1 & 2 & 3 & 5 & 7 \\
\hline Seismic & .2 & .333 & .5 & 1 & 2 & 3 & 5 \\
\hline Land use & .167 & .25 & .333 & .5 & 1 & 2 & 4 \\
\hline $\begin{array}{l}\text { Distance } \\
\text { from road }\end{array}$ & .2 & .143 & .2 & .333 & .5 & 1 & 2 \\
\hline Slope & .143 & .111 & .143 & .2 & .25 & .5 & 1 \\
\hline
\end{tabular}




\section{Landslide susceptible zonation}

Saaty's scale (Saaty 1980) of comparison was used to compare the preferences of the factors (Table 5).

Table 5: Saaty's scale of comparison

\begin{tabular}{|l|l|l|}
\hline Scale & Degree of preference & Explanation \\
\hline 1 & Equally & Two activities contribute equally \\
\hline 3 & Moderately & $\begin{array}{l}\text { Experience and judgment slightly to moderately favor one } \\
\text { activity to another }\end{array}$ \\
\hline 5 & Strongly & $\begin{array}{l}\text { Experience and judgment strongly or essentially favor one } \\
\text { activity to another }\end{array}$ \\
\hline 7 & Very strongly & $\begin{array}{l}\text { One activity is strongly favored over another and its } \\
\text { dominance is shown in practice }\end{array}$ \\
\hline 9 & Extremely & $\begin{array}{l}\text { The evidence of favoring one activity over another is to the } \\
\text { highest degree possible of an affirmation }\end{array}$ \\
\hline $2,4,6,8$ & Intermediate values & $\begin{array}{l}\text { Used to represent compromises between the preferences in } \\
\text { weights 1,3,5,7 and 9 }\end{array}$ \\
\hline
\end{tabular}

\section{Landslide susceptibility index (LSI) and Landslide susceptibility zonation}

LSI values were reclassified into 5 relative susceptibility classes viz. low, moderate, strong, very strong and extreme to prepare final landslide susceptibility zonation map (Fig. 5).

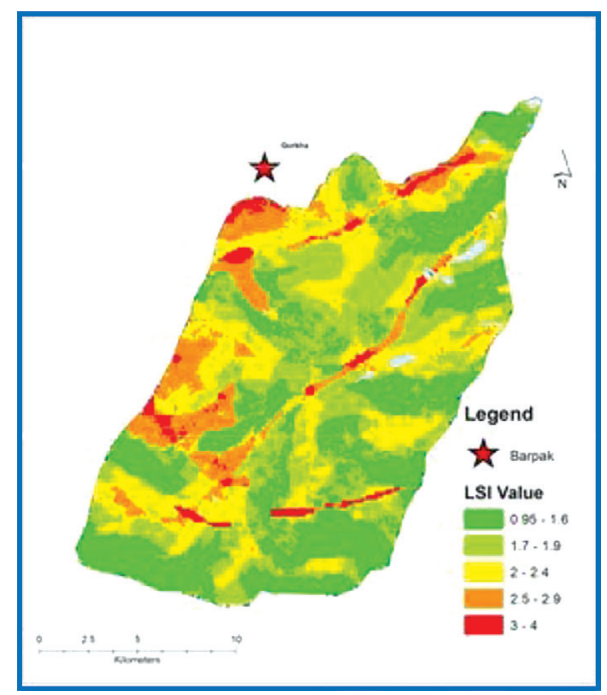

Fig. 5: Landside Susceptibility Zonation map 
The landslide susceptibility index (LSI) was found higher in the areas that are vulnerable due to earthquake and other factors. The areas that are forested, low in slope and geological stable were found less susceptible to landslide. The areas that are exposed due to roads and are near to river were found susceptible to landslide due to the load bearing, slope and river maneuvering.

The factors for the multi-criteria analysis are to some extent limited due to the data availability and the time frame of the study. However, this LSZ map gives indicative hints to plan for the necessary future action plan to manage recent landslide areas and susceptible zones.

\section{Conclusion}

There is more land degradation found in Gorkha district after the earthquake and erratic rainfall and ruptures further triggering the landslide process. The present study suggests that the landslide is influenced by many factors like; slope, distance from road and river, geology and seismic parameters, land use and relief although there are other numerous factors affecting the process. It is observed that presence of terrain conditions and slope makes the area more prone to the landslide hazards specifically causing slope failure. Distance from the river and road are factors which trigger the landslide process.

The authors recommend to such assessments like hazard zonation and triggering factors should conduct periodically so that necessary action plans can be prepared to mitigate the landslide process to support the livelihood of local people. Micro - level detailed modeling of landslide considering mentioned factors need to be performed so that triggering factors rainfall, flood and earthquake occurrence can be further analyzed to fill the gaps on landslide database.

\section{Acknowledgements}

We would like to acknowledge Department of Survey for base layers, ICIMOD, Department of Mines and Geology (DMG) for providing the necessary data to analyze the landslide susceptibility after the Gorkha Earthquake. The authors are thankful to eG-Tech Pvt. Ltd. for financial and other managerial support. 


\section{Literature Cited}

Anbalagan R., Kumar R., Parida S., Lakshmanan K. (2014): GIS based postEarthquake Landslide Hazard Zonation Mapping of Lachung Basin, Sikkim: International Journal of Emerging Technology and Advanced Engineering, vol 4, Issue 1, 441.

Anbalagan R. (1992): Landslide hazard evaluation and zonation mapping in mountainous terrain. Engineering Geology, 32, 269-277.

Delacourt C., Allemand P., Berthier E., Raucoules D.,Casson B., Grandjean P., PambrunC., Varel E. (2007): Remote-sensing techniques for analyzing land slide kinematics: Areview. Bull. Soc. Géol. Fr. 178, 89-100.

Gupta R. P., Saha A. K., Arora M. K., Kumar A. (1999): Landslide Hazard Zonation in apart of the Bhagirathi Valley GarhwalHimalayas using integrated remote sensing-GIS. Himalayan Geology, 20, 71-85.

Hutchinson J.N. (1995): Landslide hazard assessment. In Proc VI Int. Symp. On Landslides, Christchurch, 1: 1805-1842.

Saaty T.L. (1980): The analytical hierarchy process, McGraw Hill, New York.

Varnes D.J. (1984): Landslide Hazard Zonation: a review of principles and practice, UNESCO, Natural Hazards, No.3, 61. 